\title{
Effectiveness of Mechanical Brushing with Different Denture Cleansing Agents in Reducing In Vitro Candida albicans Biofilm Viability
}

\author{
Delise PELLIZZARO ${ }^{1}$ \\ Gregory POLYZOIS ${ }^{2}$ \\ Ana Lucia MACHADO ${ }^{1}$ \\ Eunice Teresinha GIAMPAOLO ${ }^{1}$ \\ Paula Volpato SANITÁ ${ }^{1}$ \\ Carlos Eduardo VERGANI ${ }^{1}$ \\ ${ }^{1}$ Department of Dental Materials and Prosthodontics, Araraquara Dental School, \\ UNESP - Univ Estadual Paulista, Araraquara, São Paulo, Brazil \\ ${ }^{2}$ Division of Removable Prosthodontics, Dental School, University of Athens, Athens, Greece
}

\begin{abstract}
The adhesion of Candida albicans to surfaces is the prerequisite for occurrence of denture stomatitis, a common disease diagnosed among denture wearers. A routine of denture cleansing is essential to prevent biofilm formation and the onset of this infection. The aim of this study was to investigate the effectiveness of combining brushing and cleansing agents in killing C. albicans biofilm. Disks of acrylic resin were made, sterilized, and inoculated with C. albicans $\left(10^{7} \mathrm{cfu} / \mathrm{mL}\right)$. After incubation $\left(37^{\circ} \mathrm{C} / 48 \mathrm{~h}\right)$, specimens were randomly assigned to 10 experimental groups $(n=9)$ : 5 subjected to brushing with distilled water or cleansing agents - dentifrice slurry, $2 \%$ chlorhexidine gluconate $(\mathrm{CHX}), 1 \%$ sodium hypochlorite $(\mathrm{NaOCl})$, and Polident fresh cleanse ${ }^{\circledR}$ (combined method) - and 4 exposed to the cleansing agents without brushing (immersion). Non-cleansed specimens were used as positive controls. The viability of cells was evaluated by XTT reduction method. Results were analyzed by Mann-Whitney and Kruskal-Wallis tests ( $\alpha=0.05)$. The combined method was significantly more effective $(\mathrm{p}<0.0001)$ in reducing biofilm viability than the immersion. Brushing with $\mathrm{CHX}$ and $\mathrm{NaOCl}$ resulted in $100 \%$ removal of the biofilm. Immersion in the agents reduced significantly $(\mathrm{p}<0.0001)$ the biofilm viability, with $\mathrm{CHX}$ being the most effective $(\mathrm{p}<0.0001)$. The use of the combined method of brushing with cleansing agents is an effective method to reduce $C$. albicans biofilm, being $\mathrm{CHX}$ and $\mathrm{NaOCl}$ the most effective solutions.
\end{abstract}

Key Words: Biofilms, Candida albicans, brushing, disinfectants, acrylic resins, denture cleansers, oral hygiene.

\section{INTRODUCTION}

The occurrence of oral candidiasis in denture wearers has been classified as denture stomatitis. This recurring condition is clinically characterized by different degrees of inflammation of the palatal mucosa under the tissue surface of the upper denture, ranging from petechiae to generalized inflammation with papillary hyperplasia. Although the multifactorial etiology of denture stomatitis is well recognized, the capacity of Candida spp. to adhere to the denture base resin and form structured biofilms has been considered one of the major factors responsible for the development of this common disease. Therefore, a strict routine of denture cleansing is essential to prevent biofilm formation on the acrylic denture surface.

The literature contains substantial data regarding the methods available for cleansing dentures, which includes mechanical brushing, chemical cleansing, or a combination of both (1-4). It has been demonstrated that brushing with dentifrice is one of the most common methods of denture hygiene (2). Paraskevas et al. (2) have reported that this method removed at least $50 \%$ of the accumulated biofilm, suggesting that the mechanical action provided by the brush was the main factor in the biofilm removing process. Although brushing with dentifrice is effective in removing the adherent biofilm cells, it has been demonstrated that the abrasive action of 
the dentifrice during brushing resulted in wear (weight loss) and increased surface roughness of denture base and relining materials (5). The increased roughness could promote higher fungal adhesion, favoring Candida colonization. The use of less or non-abrasive cleansing agents have been recommended to overcome the disadvantages of the dentifrices. In this context, chlorhexidine gluconate (CHX) has been suggested as an adjunct to denture cleansing by brushing (1). Accordingly, in combination with brushing, CHX has also shown efficacy in reducing oral biofilm $(6,7)$. In addition, evidence from clinical studies demonstrated the effectiveness of CHX gel and solution in treating patients with gingivitis (6). The antimicrobial effect of this agent is well established in the literature (3). Other disinfectants, such as sodium hypochlorite $(\mathrm{NaOCl})$, have been recommended as immersion-type chemical solutions for denture cleansing and shown effectiveness against several microorganisms, including Candida, Streptococcus, Staphylococcus, Escherichia and Bacillus (3). However, the literature does not address the antimicrobial activity of $\mathrm{NaOCl}$ combined with brushing method. Some detergent substances also have antimicrobial activity. According to the literature, sodium lauryl sulphate, a commonly employed anionic solid surfactant, has shown to confer in vivo biofilm inhibitory properties when used in toothpaste formulations (8).

Despite the broad spectrum of antimicrobial activity, some adverse effects have been related to these cleansing agents. Brushing with CHX has been associated with discoloration of natural and artificial teeth, presence of stain on the tongue, and unpleasant taste $(6,9)$. Also, it has been reported that immersion in $\mathrm{NaOCl}$ for long periods can be corrosive to metals and influence the color stability, flexural strength, roughness, and hardness of denture base resins (1012). Accordingly, it has been reported that mouthrinses with sodium lauryl sulphate resulted in complaints of unpleasant taste and painful burning sensation (8). Due to the disadvantages of these chemical solutions, an alternative for cleansing procedures could be the use of an abrasive-free foaming antibacterial denture cleanser (Polident fresh cleanse ${ }^{\circledR}$ ), which contains sodium lauryl sulphate and ethylenediaminetetraacetic acid (EDTA) (13). According to the manufacturer, when this product is used in combination with mechanical brushing, it has antimicrobial effect after a short period of exposure (90 s) (13). However, to the best of the authors' knowledge, there are no studies in the literature that investigated the antimicrobial effectiveness of this product.

The aim of the current study was to investigate the effectiveness of combining brushing and cleansing agents (dentifrice, $\mathrm{CHX}, \mathrm{NaOCl}$ and Polident fresh cleanse $^{\circledR}$ ) in killing C. albicans biofilm. The null hypothesis tested was that there are no differences among the tested denture cleansing agents.

\section{MATERIAL AND METHODS}

\section{Preparation of Acrylic Resin Specimens}

The specimens $(\mathrm{n}=90)$ were fabricated from an acrylic denture base resin (VipiWave; VIPI Indústria e Comércio Exportação e Importação de Produtos Odontológicos Ltda, Pirassununga, SP, Brazil) using a conventional flasking and pressure-pack technique. The resin cylinders were fabricated from a stainless steel mold with a breakaway compartment $(10 \times 2 \mathrm{~mm})$. This metal mold was invested in the flask in dental stone sandwiched between two glass slabs. For each specimen, $1 \mathrm{~g}$ of powder and $0.47 \mathrm{~mL}$ of monomer liquid were mixed and processed according to the manufacturer's instructions. The mixture was packed into the molds, a trial pack was completed, and excess material was removed. A final pack was performed and held for $15 \mathrm{~min}$. The denture base acrylic resin was processed in a $500 \mathrm{~W}$ domestic microwave oven (Brastemp da Amazonia SA, Manaus, AM, Brazil) for $20 \mathrm{~min}$ at $20 \%$ power, followed by $5 \mathrm{~min}$ at $90 \%$ power. The flasks were allowed to bench cool at room temperature, the specimens were deflasked, and excess flash was aseptically removed with a sterile bur (Maxi-Cut; Lesfils de August Malleifer SA, Ballaigues, Switzerland). All specimens were individually stored in distilled water at $37^{\circ} \mathrm{C}$ for $48 \mathrm{~h}$ and sterilized by microwave irradiation for $3 \mathrm{~min}$ at $650 \mathrm{~W}(14)$.

\section{Preparation of Yeast Suspension}

The standard strain of C. albicans used in this study was obtained from the American Type Culture Colection (ATCC 90028). The isolate was maintained frozen at $-70^{\circ} \mathrm{C}$ in Yeast-Peptone-Glucose (YEPD: $1 \%$ yeast extract, $2 \%$ Bacto peptone and 2\% D-glucose, $2 \%$ agar) medium until use. To prepare the yeast inoculum, the microorganism was subcultured onto Sabouraud Dextrose Agar (SDA) and incubated at $37^{\circ} \mathrm{C}$ for 48 h. Two loopfuls of this culture were transferred to 20 
$\mathrm{mL}$ of yeast nitrogen base (YNB) medium with 50 $\mathrm{mM}$ glucose and incubated at $37^{\circ} \mathrm{C}$ for $21 \mathrm{~h}$. Cells of the resultant culture were harvested and washed twice with phosphate-buffered saline (PBS, pH 7.2) at 5,000 $\mathrm{x} \mathrm{g}$ for $5 \mathrm{~min}$. Candida suspensions were resuspended in YNB supplemented with $100 \mathrm{mM}$ glucose and spectrophotometrically standardized at an optical density at $520 \mathrm{~nm}$ to a final concentration of $10^{7}$ cells $/ \mathrm{mL}$.

\section{Biofilm Development}

C. albicans biofilm were developed on the acrylic resin specimens. Briefly, the acrylic resin specimens were placed inside a pre-sterilized 24-well microtiter plates and aliquots of $2 \mathrm{~mL}$ of the standardized C. albicans cell suspension were transferred into each well. The plates were incubated for $90 \mathrm{~min}$ (adhesion phase) at $37^{\circ} \mathrm{C}$ in an orbital shaker at $75 \mathrm{rpm}$. The non-adherent cells were, then, removed from the specimens by gently washing twice with $2 \mathrm{~mL}$ PBS and $2 \mathrm{~mL}$ of freshly prepared YNB supplemented with $100 \mathrm{mM}$ glucose was added to each well. After $24 \mathrm{~h}$ incubation $\left(37^{\circ} \mathrm{C}\right.$ at $\left.75 \mathrm{rpm}\right)$, the YNB medium was removed, specimens were washed twice with PBS, and an equal volume of fresh YNB added. The microtiter plates were then incubated for further 24 $\mathrm{h}$, resulting in a final incubation time of $48 \mathrm{~h}$.

\section{Cleansing Protocols}

The 90 specimens were randomly assigned to
10 groups $(\mathrm{n}=9)$. In the control group (CG), specimens were immersed in distilled water for $90 \mathrm{~s}$. In 5 groups, specimens were subjected to a combined method of brushing with 5 different cleansing agents: distilled water; a slurry comprising one part by weight of dentifrice (Colgate Palmolive Indústria e Comércio Ltda., São Bernardo do Campo, SP, Brazil) to one part of deionized water (7); 2\% CHX (Deg Importação de Produtos Químicos Ltda., São Paulo, SP, Brazil); Polident fresh cleanse ${ }^{\circledR}$ (GlaxoSmithKline Consumer Healthcare Inc., Oakville, Ontario, Canada); and 1\% $\mathrm{NaOCl}$ (Labimpex Indústria e Comércio de Produtos para Laboratório Ltda., Diadema, SP, Brazil). In 4 groups, specimens were submitted to the chemical method of immersion for $90 \mathrm{~s}$ in $10 \mathrm{~mL}$ of each cleansing agent. This was made in order to determine the effectiveness of the cleansing agents against $C$ andida biofilm, regardless of the mechanical method. The experimental diagram of this study is shown in Figure 1.

The brushing procedures involved a mechanical brushing machine (Mavtec Comércio de Peças, Acessórios e Serviços Ltda., Ribeirão Preto, SP, Brazil). The toothbrushes used in the experiment had soft bristles and were $30 \mathrm{~mm}$ long (Classic; Colgate Palmolive Indústria e Comércio Ltda.). The portion of the bristled region of the brush head was removed and individually sterilized with ethylene oxide. The brushing machine was equipped with six brush heads, so that six specimens could be brushed simultaneously. Each specimen was immersed in $100 \mathrm{~mL}$ of the cleansing

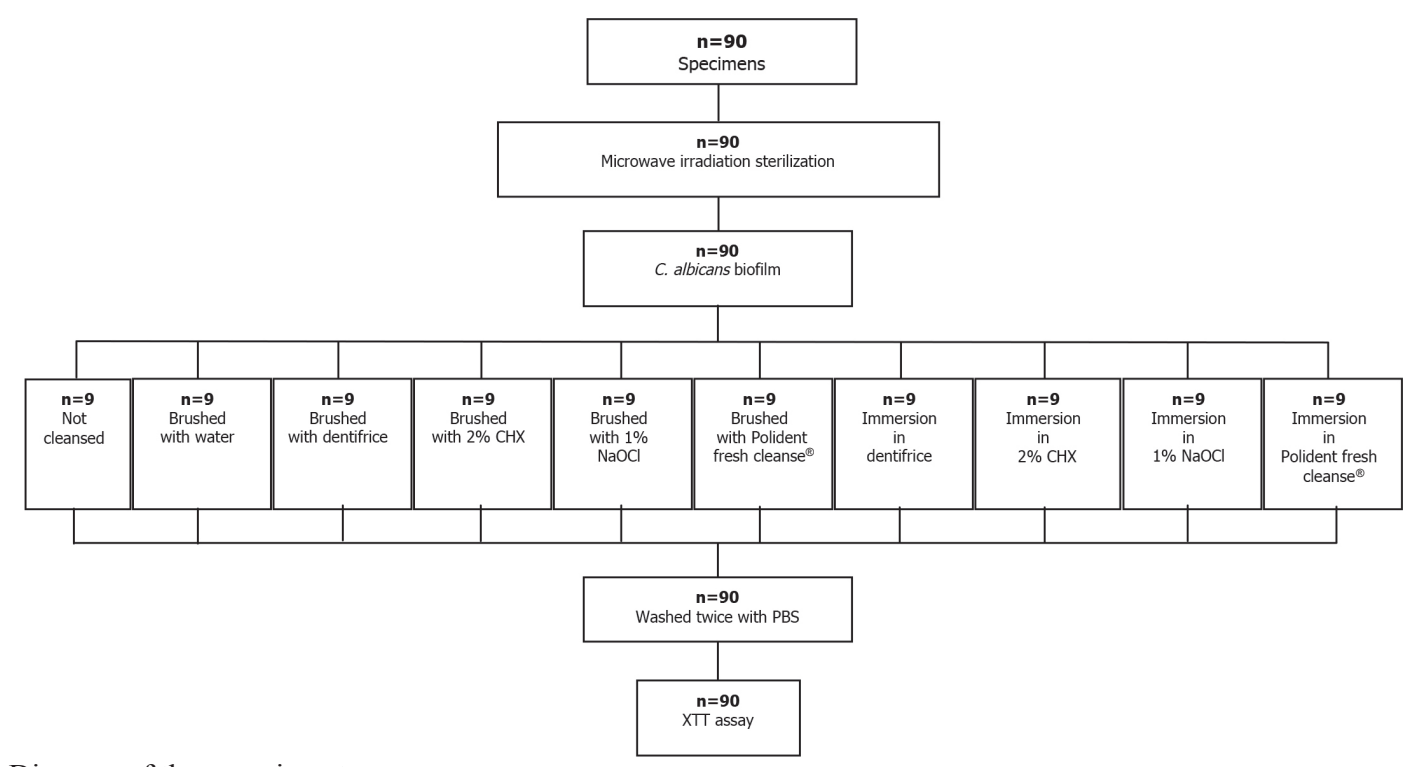

Figure 1. Diagram of the experiment. 
agent and each toothbrushing head was loaded with a $200 \mathrm{~g}$ weight and traveled horizontally for $36 \mathrm{~mm}$ at a speed of 60 reciprocal strokes per min. In total, each specimen was brushed with 90 reciprocal strokes, which is representative of one brushing session. An illustrative photograph of the brushing machine is given in Figure 2.

\section{XTT Assay}

The effect of the cleansing procedures on biofilm viability was evaluated by the XTT reduction assay. XTT (Sigma-Aldrich, St. Louis, MO, USA) was prepared in ultrapure water at a final concentration of $1 \mathrm{mg} / \mathrm{mL}$. The solution was filter sterilized and stored at $-70^{\circ} \mathrm{C}$ until use. Menadione solution (Sigma-Aldrich) was prepared in acetone at $0.4 \mathrm{mM}$ immediately before each assay. All specimens were transferred to well microtiter plates, washed twice with $2 \mathrm{~mL}$ PBS, and re-transferred to new wells with a mixture of $1,580 \mu \mathrm{L}$ PBS with $200 \mathrm{mM}$ glucose, $400 \mu \mathrm{L} \mathrm{XTT}$, and $20 \mu \mathrm{L}$ menadione in each well. The plates were incubated for $3 \mathrm{~h}$ in the dark at $37^{\circ} \mathrm{C}$. An aliquot of $1 \mathrm{~mL}$ of the solution of each well was transferred to a tube and centrifuged at 5,000 $\mathrm{x} g$ for $2 \mathrm{~min}$. The colorimetric change of the supernatant was measured using a microtiter plate reader (ThermoPlate - TPReader, Namshan District, Shenzhen, China) at $492 \mathrm{~nm}$. All experiments were performed in triplicate on three independent occasions.

\section{Statistical Analysis}

For a cleansing method to be considered effective, it has to decrease the metabolic activity (XTT assay) of the cells when compared with that obtained from the
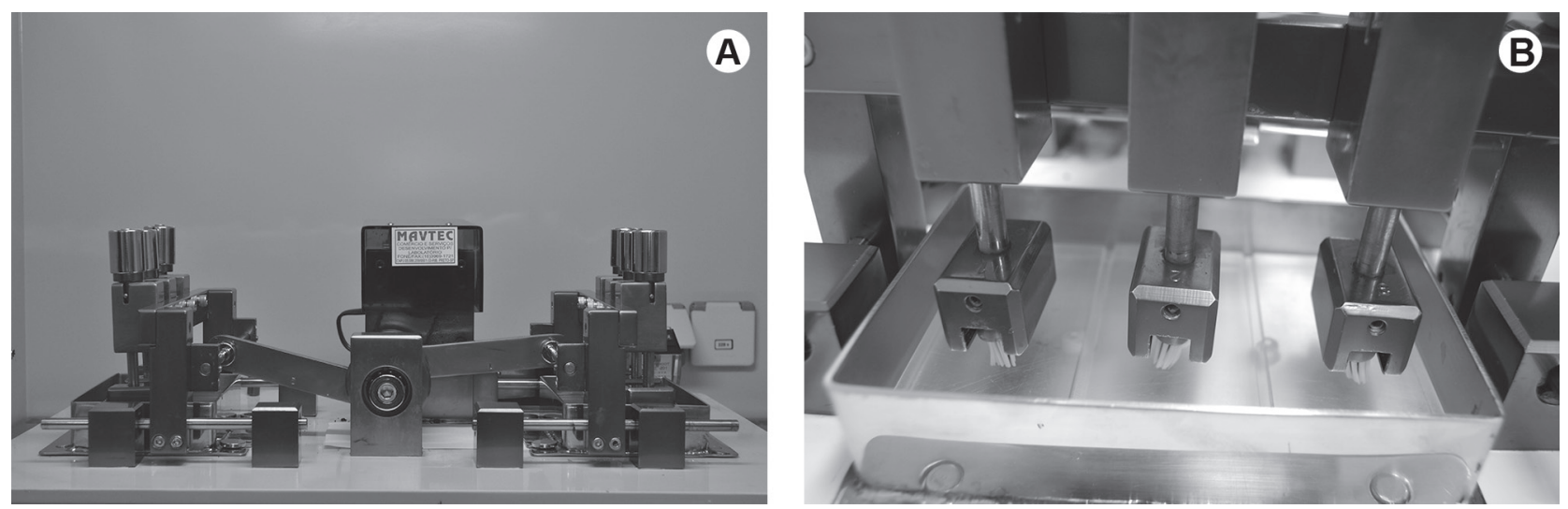

control group. The effect on the metabolic activity was measured by percentage reduction (\%) in relation to the values of absorbance obtained. The two factors analyzed were method of cleansing (brushing or immersion) and cleansing agents (water, dentifrice slurry, $1 \% \mathrm{NaOCl}$, $2 \%$ CHX and Polident fresh cleanse ${ }^{\circledR}$ ). Since the data did not satisfy the assumptions of normality and homoscedasticity (Kolmogorov-Smirnov \& Levene's tests), non-parametric statistics were performed. The between the two methods of cleansing. The results obtained from the cleansing agents for each method were compared by Kruskal-Wallis test. Differences were considered statistically significant at an $\alpha$ level of 0.05 .

\section{RESULTS}

The viability of C. albicans biofilm in relation to absorbance and percentage reduction for all experimental groups is presented in Table 1. The mean absorbance (OD at $492 \mathrm{~nm}$ ) obtained from the control group was 1.54 . All cleansing methods and agents showed statistically significant reduction in biofilm viability (absorbance) when compared with the control group. The results from Mann-Whitney test demonstrated that brushing with all agents was significantly more effective $(p<0.0001)$ in reducing biofilm viability than immersion in the cleansing agents, except for $2 \%$ CHX specimens, in which no biofilm viability was detected, regardless of the cleansing methods. When the brushing groups were compared, the Kruskal-Wallis test showed that brushing with $2 \% \mathrm{CHX}$ and $1 \% \mathrm{NaOCl}$ killed all $C$. albicans cells in the biofilm. A significant reduction in biofilm viability $(p<0.0001)$ was also observed after brushing Mann-Whitney test was used for comparative analysis

Figure 2. Frontal (A) and lateral (B) views of the brushing machine. 
with water, dentifrice slurry, and Polident fresh cleanse ${ }^{\circledR}$, with no significant differences among them $(\mathrm{p}=0.064)$. When immersed in the cleansing agents, Kruskal-Wallis test showed that $C$. albicans biofilm was completely inactivated by $2 \%$ CHX. A significant reduction in biofilm viability $(p<0.0001)$ was also promoted by the other agents, with no significant differences among them $(\mathrm{p}=0.117)$.

\section{DISCUSSION}

Amongst the most important fungal pathogens are yeast species belonging to the genus Candida, which encompasses highly virulent pathogens and are responsible for the majority of fungal infections. Denture stomatitis is one of the most common infections associated with Candida spp. It has been widely accepted that proper routine cleansing of dentures is required to prevent denture stomatitis and maintain healthy supporting tissues. Therefore, this study investigated the effectiveness of brushing with different cleansing agents in inactivating C. albicans biofilm grown on denture base resin surface. The null hypothesis that there are no differences among the denture cleansing agents was rejected.

Mechanical biofilm removal by toothbrushing is considered the most common and effective method of

Table 1. Mean absorbance values $\left(\mathrm{SD}^{*}\right)$ and percentage reduction of $C$. albicans biofilm viability.

\begin{tabular}{|c|c|c|c|c|}
\hline \multirow{3}{*}{$\begin{array}{l}\text { Cleansing } \\
\text { agents }\end{array}$} & \multicolumn{4}{|c|}{ Cleansing methods } \\
\hline & \multicolumn{2}{|c|}{ XTT OD } & \multicolumn{2}{|c|}{$\%$} \\
\hline & Brushing & Immersion & Brushing & Immersion \\
\hline Water & $0.06(0.03)$ & - & $96^{\mathrm{A}}$ & - \\
\hline Dentifrice & $0.03(0.01)$ & $0.17(0.04)$ & 98 Aa & $89^{\mathrm{Ab}}$ \\
\hline $\mathrm{CHX}$ & $0(0.00)$ & $0(0.00)$ & $100 \mathrm{Ba}$ & $100^{\mathrm{Ba}}$ \\
\hline Polident & $0.03(0.02)$ & $0.16(0.03)$ & $98^{\mathrm{Aa}}$ & $90^{\mathrm{Ab}}$ \\
\hline $\mathrm{NaOCl}$ & $0(0.00)$ & $0.19(0.02)$ & $100 \mathrm{Ba}$ & $88^{\mathrm{Ab}}$ \\
\hline
\end{tabular}

Vertically, values with the same uppercase letters were not statistically different by the Kruskal-Wallis test ( $p>0.05$ ). Horizontally, values with the same lowercase letters were not statistically different by the MannWhitney test ( $>0.05) ; *$ SD: Standard deviation. controlling plaque development (2). From the results of the present in vitro investigation, a $96 \%$ reduction on the viability of the Candida biofilm was observed after brushing with water. This reduction was probably due to the mechanical action provided by the direct contact between the bristle tips and the accumulated biofilm and the hydrodynamic shear forces of the fluid flow during brushing. Under these conditions, biofilm may be mechanically disrupted from the acrylic resin surface. However, in the study of Paraskevas et al. (2) brushing with water showed a lower reduction $(56 \%)$ on the viability of a more complex in vivo mature biofilm. Thus, it can be argued that the outcomes observed here would be different if a more complex biofilm was investigated. This highlights the importance of using antimicrobial cleansing agents in association with a brushing method. Unlike brushing, the cleansing agents act directly on specific cellular structures of the microorganisms, leading to irreversible antimicrobial effects $(15,16)$. Accordingly, this study demonstrated that exposure to all cleansing agents reduced, approximately, $90 \%$ of the $C$. albicans biofilm viability. Other investigators also showed the efficacy of these cleansing agents in inactivating microbial cells $(1,3)$. Brushing of acrylic resin with all agents showed to be more effective in reducing biofilm viability than exposure to the cleansing agents alone, except for $\mathrm{CHX}$, which was fully effective even without brushing. Paranhos et al. (17) also demonstrated that a mechanical cleansing method was as effective as its combination with chemical solutions in biofilm reduction.

In the present study, the results demonstrated that brushing with dentifrice showed a higher reduction of C. albicans biofilm viability (98\%) than brushing with water $(96 \%)$, although this difference was not statistically significant. In agreement with the results of the present study, the effectiveness of brushing with dentifrice in removing biofilms has been demonstrated (2). This can be attributed to the additional antimicrobial effect of the dentifrice selected for this study, which contains sodium monofluorophosphate (1450 ppm) and sodium lauryl sulphate. Fluorides have demonstrated some antimicrobial effects and dentifrices detergents like sodium lauryl sulphate have a variety of functions, 
including removal of organic material from tooth surface, antimicrobial effects, and a moderate biofilm inhibitory action (8). In fact, this study showed $89 \%$ reduction in the viability of $C$. albicans biofilm when the specimens were exposed to dentifrice for $90 \mathrm{~s}$ without brushing. Despite the positive cleansing effects of brushing with dentifrice, the literature contains substantial data about the adverse effects of this method on acrylic resins and artificial teeth (5). The friction between the inorganic phosphate and sulphate contents and the denture surface during brushing may result in severe damage on acrylic materials, such as wear of denture base resins and artificial teeth, with increase in roughness (5). Surface roughness is known to be a factor in the entrapment of microorganisms on surfaces and their protection from shear forces, which can result in a higher trend to biofilm accumulation.

CHX has been widely used in several areas as a disinfectant agent due to its broad spectrum of antimicrobial activity $(1,3)$. The results of this study showed that, after $90 \mathrm{~s}$ of exposure, $2 \% \mathrm{CHX}$ solution killed $C$. albicans biofilm, with and without brushing. This effect can be attributed mainly to the chemical mechanism of action of this solution against the fungal cell (15). MacNeill et al. (15) observed that, after the contact with CHX, C. albicans cells exhibited a severe cytoplasmic degeneration (fragmentation and clumping of the contents, vacuolization, lipid accumulation, and condensation) and fragmentation and desquamation of the cell wall, resulting in cell death. The literature contains substantial data relating to the use of $\operatorname{CHX}(1,3)$. The in vitro effectiveness of this solution against several microorganisms has been demonstrated (3), while an in vivo study reported positive results of toothbrushing in promoting biofilm and gingivitis reduction (6). Moreover, other investigators found that immersion of complete dentures in CHX was satisfactory in controlling biofilm $(1,7)$.

The effective protocol used here was based on previous reports with some modifications. Pavarina et al. (1) established a protocol of disinfection in which 10 min of immersion at $4 \%$ concentration solution was effective in removing in vivo biofilm from complete dentures. However, 4\% CHX solution has shown to negatively affect the hardness and roughness of acrylic resins (10). Considering that the deleterious effects on acrylic resins are affected by concentration and exposure time, studies were undertaken to test the antimicrobial efficacy of lower concentrations and periods. Exposure to $2 \%$ CHX during short periods of time (3 and $10 \mathrm{~min}$ ) was effective to eradicate mature biofilms of different microorganisms (3). In the present investigation, a very short period of exposure (90 s) to $2 \% \mathrm{CHX}$ was sufficient to completely inactivate $C$. albicans biofilm on an acrylic resin, which could be one of the most important findings of this study. Regardless of its effectiveness, the use of CHX has been limited by some side effects that could affect the patient compliance. Discolorations of the tongue (9) and natural teeth (6) have been reported after prolonged use (1 to 6 months). Moreover, its bitter taste can reduce the patient's compliance (6).

From the results of the present investigation, a complete reduction $(100 \%)$ of C. albicans biofilm viability was observed when $1 \% \mathrm{NaOCl}$ was used as an adjunct to brushing. It was also observed that, without brushing, exposure of the specimens in $1 \% \mathrm{NaOCl}$ during 90 s promoted $88 \%$ of reduction on C. albicans biofilm viability. These results are consistent with data from another report, in which, although very small in number, some viable $C$. albicans cells remained on acrylic surfaces after a longer time of immersion (10 min) in $1 \%$ $\mathrm{NaOCl}$ (3). The clinical relevance of this fact is that the surviving cells have the ability to resurrect the biofilm, sustain a source of contamination, and, consequently, create a persistent infection. Thus, as observed in the present study, the mechanical action provided by the brushing is essential in order to achieve a complete inactivation of $C$. albicans biofilm on acrylic denture. The antimicrobial mechanism of action of $\mathrm{NaOCl}$ has been related to its physicochemical characteristics and its reaction with organic tissues and microorganisms. $\mathrm{NaOCl}$ is a strong base $(\mathrm{pH}>11)$ and its high $\mathrm{pH}$ alters the integrity of the cytoplasmic membrane by means of either chemical injuries to organic components and transport of nutrient, or degradation of phospholipids or unsaturated fatty acids of the cytoplasmic membrane. This causes an irreversible enzymatic inhibition and biosynthetic alterations in cellular metabolism, resulting in cell death (16). Despite the effectiveness of brushing with $1 \% \mathrm{NaOCl}$ in removing biofilm, this cleansing procedure may have some disadvantages, such as the detrimental effects on acrylic materials $(10,18,19)$. A decrease in hardness and increase in roughness were observed after immersion of acrylic materials in $2 \%$ $\mathrm{NaOCl}$ solution for $5 \mathrm{~min}(10)$. In addition, its corrosive activity on metal surfaces is widely known. However, no significant changes in hardness and roughness of acrylic resins were observed when the $1 \%$ concentration was 
used for $10 \mathrm{~min}$ (20). In addition, McNeme et al. (21) demonstrated no detectable color changes in acrylic resin after $72 \mathrm{~h}$ of immersion in $1 \% \mathrm{NaOCl}$. Thus, it could be expected that the protocol of brushing with $1 \%$ $\mathrm{NaOCl}$ during a short period of time ( $90 \mathrm{~s}$ ) may produce consistent eradication of $C$. albicans biofilm without the detrimental effects discussed above.

The results of this study demonstrated that brushing with Polident fresh cleanse ${ }^{\circledR}$ reduced $98 \%$ of the $C$. albicans biofilm viability. A significant lower reduction $(90 \%)$ on biofilm viability was also observed after $90 \mathrm{~s}$ of exposure to this cleansing agent. These data are consistent with those observed for the other cleansing agents investigated here. The antimicrobial effect of this cleansing agent may be related to the presence of sodium lauryl sulphate and EDTA in its composition. According to some studies, sodium lauryl sulphate and EDTA have shown antimicrobial action against different microorganisms $(8,22,23)$. The mechanism of action of sodium lauryl sulphate seems to be related to its adsorption and penetration through the porous cell wall (24). This causes an increase in cell permeability, which may result in leakage of intracellular components and cell lysis (24). Similarly, the antimicrobial mechanism of action of the EDTA on the metabolic activity of microorganisms seems also to be related to structural damages to cell membranes (25). Such damages increase the permeability of the membranes and improve the action of other antibacterial agents (25). In fact, an in vitro study demonstrated that EDTA reduced $99 \%$ of biofilmassociated $P$. aeruginosa cells and, when combined to gentamicin, it eradicated the cells completely (23). EDTA has also been shown to effectively prevent the growth of microbial organisms that generate and reside within biofilms, since it inhibits filamentation and biofilm formation of C. albicans (22). Considering these data and the results of the present study, it can be speculated that both sodium lauryl sulphate and EDTA were responsible for the antimicrobial activity of Polident fresh cleanse ${ }^{\circledR}$. Although all cleansing agents were effective in reducing the viability of $C$. albicans biofilm, Polident fresh cleanse ${ }^{\circledR}$ may provide further advantages. This product contains no abrasive agents, which would prevent several damages on acrylic materials, such as wear of acrylic resin and artificial teeth, and increased in roughness on their surfaces. Despite the positive results in reducing $C$. albicans biofilm viability obtained with Polident fresh cleanse $^{\circledR}$, further studies should be conducted in order to evaluate its spectrum of antimicrobial activity and its possible effects on the properties of denture materials. Within the limitations of this in vitro study, it can be concluded that all groups subjected to the toothbrushing method with different cleansing agents presented a significant reduction in C. albicans biofilm viability; toothbrushing with $2 \% \mathrm{CHX}$ and $1 \% \mathrm{NaOCl}$ reduced $100 \%$ the viability of $C$. albicans biofilm; and the mechanical action of toothbrushing method is an important factor on biofilm reduction.

\section{RESUMO}

A adesão de Candida albicans às superfícies é o primeiro passo para o desenvolvimento da estomatite protética, uma infecção frequente diagnosticada entre os usuários de próteses. Uma adequada higienização é essencial para prevenir a formação de biofilme microbiano e o início desta infecção. O objetivo deste estudo foi avaliar a efetividade da escovação com diferentes soluções na eliminação de biofilme de C. albicans. Para isso, discos de resina acrílica foram confeccionados, esterilizados e inoculados com uma suspensão de $10^{7}$ células $/ \mathrm{mL}$ de C. albicans. Após incubação $\left(37^{\circ} \mathrm{C} / 48 \mathrm{~h}\right)$, os espécimes foram aleatoriamente divididos em 10 grupos experimentais $(n=9)$ : 5 submetidos à escovação com água ou agentes de limpeza (água destilada, dentifrício, digluconato de clorexidina (CHX) a $2 \%$, hipoclorito de sódio $(\mathrm{NaOCl})$ a $1 \%$ e Polident fresh cleanse $\left.{ }^{\circledR}\right)$ e 4 apenas imersos nos agentes de limpeza. Espécimes não submetidos à higienização foram utilizados como controle positivo. A viabilidade celular foi verificada pelo teste de redução do XTT. Os resultados obtidos foram analisados pelos testes de Mann-Whitney e KruskalWallis $(\alpha=0,05)$. A escovação com todos os agentes de limpeza apresentou redução significativamente superior $(p<0,0001)$ na viabilidade do biofilme quando comparada à exposição dos espécimes às soluções. Escovação com $\mathrm{CHX}$ a 2\% e NaOCl a 1\% resultaram em $100 \%$ de inativação do biofilme. A exposição aos agentes de limpeza resultou em redução significativa $(\mathrm{p}<0,0001)$ na viabilidade celular, com $\mathrm{CHX}$ a $2 \%$ sendo o mais efetivo $(\mathrm{p}<0,0001)$. A utilização de agentes de limpeza em associação ao método de escovação provou ser efetivo para reduzir biofilme $C$. albicans, sendo as soluções de $\mathrm{CHX}$ e $\mathrm{NaOCl}$ as mais efetivas.

\section{ACKNOWLEDGEMENTS}

This work was supported by FAPESP - The São Paulo Research Foundation (Grant 2010/06578-6) and CAPES - Coordination for the Improvement of Higher Level or Education Personnel.

\section{REFERENCES}

1. Pavarina AC, Pizzolitto AC, Machado AL, Vergani CE, Giampaolo ET. An infection control protocol: effectiveness of immersion solutions to reduce the microbial growth on dental prostheses. J Oral Rehabil 2003;30:532-536.

2. Paraskevas S, Rosema NA, Versteeg P, Timmerman MF, van der Velden U, van der Weijden GA. The additional effect of a dentifrice on the instant efficacy of toothbrushing: a crossover study. J Periodontol 2007;78:1011-1016. 
3. Silva FC, Kimpara ET, Mancini MN, Balducci I, Jorge AO, Koga-Ito CY. Effectiveness of six different disinfectants on removing five microbial species and effects on the topographic characteristics of acrylic resin. J Prosthodont 2008;17:627-633.

4. Felton D, Cooper L, Duqum I, Minsley G, Guckes A, Haug S, et al.. American College of Prosthodontists. Evidence-based guidelines for the care and maintenance of complete dentures: a publication of the American College of Prosthodontists. J Prosthodont 2011;20 Suppl 1:S1-S12.

5. Mendonça MJ, Machado AL, Giampaolo ET, Pavarina AC, Vergani CE. Weight loss and surface roughness of hard chairside reline resins after toothbrushing: influence of postpolymerization treatments. Int J Prosthodont 2006;19:281-287.

6. Bassiouny MA, Grant AA. The toothbrush application of chlorhexidine. A clinical trial. Braz Dent J 1975;139:323-327.

7. Andrade IM, Cruz PC, Silva-Lovato CH, Souza RF, SouzaGugelmin MC, Paranhos HF. Effect of chlorhexidine on denture biofilm accumulation. J Prosthodont 2012;21-26.

8. Jenkins S, Addy M, Newcombe R. Triclosan and sodium lauryl sulphate mouthrinses. (II). Effects of 4-day plaque regrowth. J Clin Periodontol 1991;18:145-148.

9. Van Strydonck DA, Timmerman MF, Van der Velden U, Van der Weijden F. Clinical efficacy of a chlorhexidine-delivering toothbrush. J Clin Periodontol 2008;35:584-590.

10. Pinto LR, Acosta EJ, Távora FF, Silva PM, Porto VC. Effect of repeated cycles of chemical disinfection on the roughness and hardness of hard reline acrylic resins. Gerodontology 2010;27:147-153.

11. Felipucci DN, Davi LR, Paranhos HF, Bezzon OL, Silva RF, Barbosa Junior F, et al.. Effect of different cleansers on the weight and ion release of removable partial denture: an in vitro study. J Appl Oral Sci 2011;19:483-487.

12. Felipucci DN, Davi LR, Paranhos HF, Bezzon OL, Silva RF, Pagnano VO. Effect of different cleansers on the surface of removable partial denture. Braz Dent J 2011;22:392-397.

13. Eoga $\mathrm{ABJ}$. Liquid denture cleanser composition and method of application. PatentStorm. Available from: http://www.patentstorm. us/patents/4701223/fulltext.html. Latest access: October 30, 2012

14. Sanitá PV, Vergani CE, Giampaolo ET, Pavarina AC, Machado AL. Growth of Candida species on complete dentures: effect of microwave disinfection. Mycoses 2009;52:154-160.

15. MacNeill S, Rindler E, Walker A, Brown AR, Cobb CM. Effects of tetracycline hydrochloride and chlorhexidine gluconate on Candida albicans. An in vitro study. J Clin Periodontol 1997;24:753-760.

16. Estrela C, Estrela CR, Barbin EL, Spanó JC, Marchesan MA, Pécora JD. Mechanism of action of sodium hypochlorite. Braz Dent J 2002;13:113-117.

17. Paranhos HF, Silva-Lovato $\mathrm{CH}$, de Souza RF, Cruz PC, de Freitas-Pontes KM, Watanabe E, et al.. Effect of three methods for cleaning dentures on biofilms formed in vitro on acrylic resin. J Prosthodont 2009;18:427-431.

18. Paranhos HF, Davi LR, Peracini A, Soares RB, Lovato CH, Souza RF. Comparison of physical and mechanical properties of microwave-polymerized acrylic resin after disinfection in sodium hypochlorite solutions. Braz Dent J 2009;20:331-335.

19. Peracini A, Davi LR, Ribeiro NQ, Souza RF, da Silva CHL, Paranhos HFO. Effect of denture cleansers on physical properties of heat-polymerized acrylic resin. J Prosthodont Res 2010;54:7883.

20. Azevedo A, Machado AL, Vergani CE, Giampaolo ET, Pavarina AC, Magnani R. Effect of disinfectants on the hardness and roughness of reline acrylic resins. J Prosthodont 2006;15:235-242.

21. McNeme SJ, von Gonten AS, Woolsey GD. Effects of laboratory disinfecting agents on color stability of denture acrylic resins. J Prosthet Dent 1991;66:132-136.

22. Ramage G, Wickes BL, López-Ribot JL. Inhibition on Candida albicans biofilm formation using divalent cation chelators (EDTA). Mycopathologia 2007;164:301-306.

23. Banin E, Brady KM, Greenberg EP. Chelator-induced dispersal and killing of Pseudomonas aeruginosa cells in a biofilm. Appl Environ Microbiol 2006;72:2064-2069.

24. Salton MR. Lytic agents, cell permeability, and monolayer penetrability. J Gen Physiol 1968;52:227-252.

25. Nikaido H. Molecular basis of bacterial outer membrane permeability revisited. Microbiol Mol Biol Rev 2003;67:593-656.

Received April 13, 2012

Accepted September 25, 2012 